\title{
The Meruliaceae of Russia. I. Bjerkandera
}

\author{
I. V. Zmitrovich, M. A. Bondartseva, N. P. Vasilyev \\ Komarov Botanical Institute, BIN RAS, Prof. Popov, 2, St.Petersburg, 197376, Russia, E-mail: IZmitrovich@binran.ru
}

Key words: basidiomycetes, aphyllophoralean fungi, meruliaceous fungi, modifications variability, broadleaf woodassociated fungi, Russia, Saint Petersburg parks.

Summary. This paper opens a taxonomical survey on the genera of Meruliaceae (Polyporales, Basidiomycota) presented in Russian mycobiota. All the meruliaceous fungi represent an obligate component of heterotrophic block of forest ecosystems and considerable demanded biotechnological resource. The purpose of the present elaboration is a revision of East European and North Asian material on Bjerkandera genus highlighting its species' and intraspecific morphological variability and substrate specialization. The macroscopic descriptions are based on a study of fresh and dried specimens. The material of the herbaria of Komarov Botanical Institute (St. Petersburg, LE) and Institute of Zoology and Botany of Estonian Agricultural University (TAA) is studied. Micromorphological analysis is included the hyphal system revealing, the hyphae, basidia/basidiospores morphometry, and microchemical tests of the structures in question. The genus Bjerkandera is accepted in its original Karstenian sense, although the concepts by Pilát, Corner, Pouzar, and Zmitrovich et al. were discussed. The genus is characterized by two-layered context with rather loose tomentum and dense layer above the hymenophore, monomitic to pseudodimitic hyphal system, clamped generative hyphae, and ellipsoid-cylindrical basidiospores not staining in Cotton blue and Melzer's reagent. Only two species, Bjerkandera adusta and B. fumosa were recognized in the genus, and a possible position of B. subsimulans and $B$. terebrans was discussed, too. The polymorphism of $B$. adusta is exhaustively presented and the form tegumentosa was epitypified and described. The polymorphism of $B$. fumosa is also presented, and the form flavipora was correctly published and epitypified. The relationships between two species are discussed and the key for species delimitation is presented here. Distributional patterns are presented for both species as well as their substrate range. The substrates of B. adusta and B. fumosa in old-growth arboreta of Saint Petersburg are presented.

\section{Мерулиевые грибы России. I. Род Bjerkandera}

\author{
И. В. Змитрович, М. А. Бондарцева, Н. П. Васильев \\ Ботанический институт им. В. Л. Комарова, БИН РАН, Проф. Попова, 2, Санкт-Петербург, 19737б, Россия
}

Ключевые слова: базидиомицеты, афиллофоровые грибы, мерулиевые грибы, модификационная изменчивость, грибы широколиственных пород, Россия, парки Санкт-Петербурга.

Аннотация. Статья открывает таксономический обзор родов семейства Meruliaceae (Polyporales, Basidiomycota), представленных в микобиоте России. Мерулиевые грибы представляют облигатный компонент гетеротрофного блока лесных экосистем и значительный биотехнологический ресурс. Цель данной работы - таксономическая обработка восточноевропейского и североазиатского материала по роду Bjerkandera, с особым вниманием к описанию внутривидового полиморфизма. Макроскопические описания основаны на исследовании свежих и высушенных образцов, хранящихся в гербариях Ботанического института им. В. Л. Комарова (г. Санкт-Петербург, Россия, LE) и Института Зоологии и ботаники Сельскохозяйственного университета г. Тарту (Эстония, ТАА). Микроморфологический анализ включал выявление гифальной системы, морфометрию гиф, базидий и спор и микрохимические тесты структур. Род Bjerkandera принят в его оригинальной трактовке П. Карстеном, хотя обсуждены также концепции А. Пилата, Э. Корнера, З. Поузара и И. В. Змитровича и соавторов. Род характеризуется двухслойной тканью с рыхлым верхним слоем и темной линией над 
гименофором, мономитической или псевдодимитической гифальной системой, пряжками на генеративных гифах и эллипсоидально-цилиндрическими базидиоспорами, не изменяющими окраски в реактиве Мельцера и Хлопчатобумажном синем. В роде принимается два вида-Bjerkandera adusta и B. fumosa. Таксономическое положение B. subsimulans и B. terebrans требует корректировки. Подробно описан внутривидовой полиморфизм $B$. adusta, причем произведена эпитипификация f. tegumentosa. Представление полиморфизма $B$. fumosa сопровождается корректным оформлением и эпитипификацией f. flavipora. Подробно обсуждена проблема разграничения двух видов и представлен видовой ключ. Собран материал по географическому распространению двух видов и их субстратной приуроченности, включая полученные авторами данные о субстратной приуроченности видов, выявленной в старовозрастных посадках широколиственных пород на территории г. Санкт-Петербурга.

This paper opens a taxonomical survey on the genera of Meruliaceae (Polyporales, Basidiomycota) presented in Russian mycobiota. The Meruliaceae family unites a certain corticioid (Zmitrovich, 1997), some polyporoid (Binder et al., 2013) and even lentinoid (Zmitrovich, Malysheva, 2013) fungi associated to the wood in various stages of humification and causing a white rot. All the meruliaceous fungi represent an obligate component of heterotrophic block of forest ecosystems and considerable demanded biotechnological resource.

The genus Bjerkandera was described by P. Karsten (1879) for annual tyromycetoid polypores characterized by colored pore layer which is separated from the context by a dense zone. The generic name refers to Clas Bjerkander (1735-1795), a Swedish naturalist. During a long time, the genus kept two species, B. adusta (Willd.) P. Karst. and B. fumosa (Pers.) P. Karst., but initially it contained also B. dichroa (Fr.) P. Karst. [= Gloeoporus dichrous (Fr.) Bres.], B. amorpha (Fr.) P. Karst. [= Skeletocutis amorpha (Fr.) Kotl. et Pouzar], B. kymatodes (Fr.) P. Karst. (= Skeletocutis amorpha), B. diffusa (Fr.) P. Karst. (an ambiguous species), and $B$. isabellina (Fr.) P. Karst. (a synonym of B. adusta in current use). Ames (1913) and later Donk (1974), who have adhered two-species concept of the genus, wrote about the distinct layer which precedes a tubes formation and that this layer is highly characteristic.

Further, various authors included the type $B$. adusta (and, therefore, the genus as a whole) into such genera as Gloeoporus Mont. (Pilát, 1937; Corner, 1989), Tyromyces P. Karst. (Pouzar, 1966) or Grifola Gray (Zmitrovich et al., 2006).

The reasons for inclusion of Bjerkandera type to the Gloeoporus were two-layered nature of tyromycetoid basidiocarps and a certain degree of gelatinization of hymenophoral tissues. However, as it was noted by Corner (1989), the degree of tube gelatinization is rudimentary in G. adustus (Willd.) Pilát and G. fumosus (Pers.) Pilát - in contrast to $G$. dichrous and some tropical genus representatives.
The reasons for merging of Bjerkandera into Tyromyces were a monomitic hyphal system in both genera and rather comparable tyromycetoid morphotypes. Further, it was shown that the hyphal system in tyromycetoid fungi is rather diverse and that Bjerkandera basidiocarps have a morphotype intermediate between grifoloid and tyromycetoid ones, therefore, both B. adusta and B. fumosa were moved into the Grifola.

A recent molecular testing of polypore genera confirms a monophyletic nature of $B$. adusta/B. fumosa grouping as a sister lineage of indigo-colored corticioid Terana coerulea (Lam.) Kuntze (Floudas, Hibbett, 2015). A great work on corrections of sequences misidentifications in Bjerkandera adusta/B. fumosa pair was provided by Jung et al. (2014).

The purpose of the present elaboration is a revision of East European and North Asian material on $B$. adusta and $B$. fumosa highlighting their intraspecific morphological variability and substrate specialization.

\section{Materials and Methods}

The macroscopic descriptions were based on a study of fresh and dried specimens. The materials of the herbaria of Komarov Botanical Institute (St. Petersburg, Russia, LE) and Institute of Zoology and Botany of Estonian Agricultural University (Estonia, TAA) were studied. Microscopic preparations were mounted from dried material in Melzer's solution, $10 \%$ ammoniacal Congo Red and $5 \%$ aqueous solution of $\mathrm{KOH}$, using a LOMO Micmed-6 light microscope. The hyphal system was revealed and described according to updated technique (Zmitrovich et al., 2009). The size of mature spores was measured on 30 spores in distilled water and Melzer's solution.

\section{Results and Discussion}

Meruliaceae Rea, 1922, British Basid.: 620.

Phanerochaetoideae (Jülich) Parmasto, 1986, Windahlia, 16: 17. 
Bjerkandera P. Karst., 1879, Medd. Soc. Fauna Fl. Fenn., 5: 38.

= Myriadoporus Peck, 1884, Bull. Torrey Bot. Cl., 11, 3: 27.

Basidiocarp annual or wintering, pileate, decurrent to prostrate, soft to pliable. Upperside when present subtomentose, matt or rugulose at drying, hygrophanous. Context two-layered with rather loose tomentum and dense layer above the hymenophore. Hymenophore as a single tube layer of ceraceous consistency. Hyphal system monomitic in the tubes and pseudodimitic in the context. Generative hyphae with clamp connections. Cystidia none. Basidia clavate with median constriction, 4-spored, with a basal clamp. Basidiospores ellipsoid-cylindric, smooth, thin-walled, negative in Melzer's reagent. Worldwide distributed oligotypic genus associated to the white-rot of hardwoods, rarely conifers.

Type species: Polyporus adustus Willd.: Fr., 1821, Syst. Mycol., 1: 363 (selected by Murrill, 1903).

Type specimen is deposited in Friesian herbarium of the Uppsala University Museum of Evolution (Sweden, UPS) marked as "Finland, Mustiala, leg. P. Karsten“ (Ryvarden, 1991).

Anamorph: Geotrichum-like (Romero et al., 2007).

In Eurasian continent the genus contains two polymorphic species characterized below. In Americas, two additional species, Bjerkandera atroalba (Rick) Westphalen et al. and B. centroamericana Westphalen et al. (Westphalen et al., 2015), plus some ambiguous Murrill's taxa were reported.

\section{Key to species}

1. Pores 6-7 per $\mathrm{mm}$, pore surface combines whitish (tube mouths) and smoky-gray to grayishblack tinges, dense zone above tubes is grayishblack

1. B. adusta

- Pores (1)2-4(5) per mm, pore surface combines whitish (tube mouths) and buff to isabelline tinges, dense zone above tubes is brownish-cinnamon

2. B. fumosa

1. Bjerkandera adusta (Willd.: Fr.) P. Karst., 1879, Medd. Soc. Fauna Fl. Fenn. 5: 38. $\equiv$ Boletus adustus Willd., 1787, Fl. Berol. Prodr.: 392. Polyporus adustus Willd.: Fr., 1821, Syst. Mycol., 1: 363. - Leptoporus adustus (Willd.: Fr.) Quél., 1886, Enchir. Fung.: 177. - Polystictus adustus (Willd.: Fr.) Gillot et Lucand, 1890, Bull. Soc. Hist. Nat. Autun, 3: 173. - Gloeoporus adustus (Willd.: Fr.) Pilát in Kavina et Pilát, 1937, Atlas Champ.
Eur., 3: 137. - Tyromyces adustus (Willd.: Fr.) Pouzar, 1966, Folia Geobot. Phytotax. Bohemoslov., 1: 370. - Grifola adusta (Willd.: Fr.) Zmitr. et Malysheva in Zmitr., Malysheva et Spirin, 2006, Mycena, 6: 21 .

= Boletus fuscoporus J.J. Planer, 1788, Ind. P1. erfurt. Fung. add.: 26.

= B. pelloporus Bull., 1791, Hist. Champ. France: 365 .

=B. carpineus Sowerby, 1799, Col. Fig. Engl. Fung. Mushr., 2: pl. 231.

= B. crispus Pers., 1800 ("1799”), Observ. Mycol., 2: 8 .

= B. concentricus Schumach., 1803, Enum. P1., 2: 387.

= Poria argentea Ehrenb., 1818, Sylv. Mycol. Berol.: 31.

= Boletus isabellinus Schwein., 1822, Schr. Naturf. Ges. Leipzig 1: 96.

= Polyporus murinus Rostk. in Sturm, 1838, Deutschl. Fl., 3, Abt. 4: 117.

$=P$. subcinereus Berk., 1839, Ann. Nat. Hist., Mag. Zool. Bot. Geol., 3: 391.

$=P$. halesiae Berk. et M.A. Curtis, 1853, Ann. Mag. Nat. Hist., Ser. 2, 12: 434.

$=P$. scanicus Fr., 1863, Monogr. Hymenomyc. Suec., 2, 2: 269.

$=P$. lindheimeri Berk. et M.A. Curtis, 1872, Grevillea, 1, 4: 50 .

=P. fumosogriseus Cooke et Ellis, 1881, Grevillea, 9, 51: 103.

= Daedalea oudemansii var. fennica P. Karst., 1882, Medd. Soc. Fauna Fl. Fenn., 9: 69.

= Myriadoporus adustus Peck, 1884, Bull. Torrey Bot. Cl., 11, 3: 27.

= Polystictus gloeoporoides Speg., 1889, Boln Acad. Nac. Cienc. Córdoba, 11, 4: 451.

= Polyporus macrosporus Britzelm., 1894, Ber. Naturw. Ver. Schwaben, 31: 174.

$=P$. ochraceocinereus Britzelm., 1895, Botan. Zbl., 62: 311 .

$=$ P. burtii Peck, 1897, Bull. Torrey Bot. Cl., 24: 146.

$=$ Coriolus alabamensis Murrill, 1907, N. Amer.

F1., 9, 1: 19.

= Polyporus excavatus Velen., 1922, České Houby, 4-5: 641 .

$=P$. cinerascens Velen., ibid.: 642 .

$=P$. atropileus Velen., 1925, Mykologia (Prague), 2: 74 .

= P. tegumentosus Velen., ibid.: 74 .

= Daedalea solubilis Velen., 1926, Mykologia (Prague), 3: 102. 
Ic on.: Bulliard (1790: pl. 501, 2, ut Boletus pelloporus); Rostkovius (1837: tab. 38 ut Polyporus adustus); Kennedy, Larcade (1971: figs 1-12, ut Polyporus adustus); Phillips (1981: p. 236); Breitenbach, Kränzlin (1986: fig. 329); Gilbertson, Ryvarden (1986: fig. 65); Ryvarden, Gilbertson (1993: fig. 72); Roy, De (1996: fig. 13); Bernicchia (2005: fig. 140; pl. p. 610); Niemelä (2005: fig. 53); Jung et al. (2014: fig. 1A); Ryvarden, Melo (2014: fig. 76).

Basidiocarps $1-4.5 \times 2-10 \times 0.3-1.5 \mathrm{~cm}$, annual (wintering), as sessile, decurrent or patch-like resupinate clustering pilei of toughfleshy consistency. Upperside (when present) subtomentose to matt or rugulose at drying, cream to isabelline with gray tinges, often with pale or subochraceous obscure zonation, grayish or bluegrayish along the margin, rather loose and spongy. The margin as a rule acute, sometimes border-like, slightly undulating, white, then with cineraceous shades, sterile up to $2 \mathrm{~mm}$ at the maturity. Context two layered with rather loose light cream or grayish upper layer $0.2-1 \mathrm{~cm}$ thick and dense grayishblack layer (so-called "black line") above the hymenophore. Hymenophore as a single tube layer $0.02-0.5 \mathrm{~cm}$ thick of ceraceous consistency, initially cream, then smoky-gray to blackish mouse-gray. Pores 6-7 per mm, angular, rather thin-walled; pore surface combines whitish (tube mouths) and smokygray to grayish-black tinges (fig. 1).

Hyphal system monomitic in the tubes and pseudodimitic in context. Generative hyphae 2-4 $\mu \mathrm{m}$ in diam., regularly branched at acute margin, with regular clamp connections. Pseudoskeletal hyphae 3-6(10) $\mu \mathrm{m}$ in diam., fibrous or ramified, thickwalled to subsolid in $\mathrm{KOH}$, in some parts swelling at $10 \mu \mathrm{m}$ in cross. Cystidia none. Basidia $10-15 \times 4-5.5$ $\mu \mathrm{m}$, clavate with median constriction, 4-spored, with a basal clamp. Basidiospores (4)4.3-5.5(6.5) $\times$ (2.2)2.5-3.5 $\mu \mathrm{m}$, ellipsoid-cylindric, smooth, thinwalled, negative in Melzer's reagent (fig. 2).

On dying trees, fallen logs and branches, stumps, buried wood and small debris of many hardwoods, rarely conifers, causing a white rot. For pathogenic significance - see Brooks (1925).

Substrata: Acacia, Acer, Aesculus, Ailanthus, Alnus, Betula, Carpinus, Castanea, Celtis, Corylus, Crataegus, Cytisus, Eucalyptus, Fagus, Fraxinus, Juglans, Larix, Malus, Myoporum, Olea, Platanus, Populus, Prunus, Rhamnus, Robinia, Rosa, Quercus, Salix, Sambucus, Sorbus, Syringa, Tamarix, Tilia, Ulmus, Abies, Larix, Picea, Pinus (Țura et al., 2011; Bondartseva et al., 2014; Ryvarden, Melo, 2014).
General distribution: EUROPE (Austria, Belarus, Belgium, Bulgaria, Croatia, Czech Republic, Denmark, Estonia, Finland, France, Germany, Greece, Hungary, Italy, Latvia, Lithuania, the Netherlands, Norway, Poland, Portugal, Romania, Russia, Slovenia, Spain, Sweden, Switzerland, Ukraine, United Kingdom); SOUTH AMERICA (Argentina, Brazil, Chile); CENTRAL AMERICA (Costa Rica, Cuba); NORTH AMERICA (Canada, Mexico, USA); ASIA (Armenia, Azerbaijan, Georgia, Iran, Israel, Japan, Korea, Mongolia, Nepal, Russia, Sri Lanka, Turkey); SOUTHERN HEMISPHERE (Papua New Guinea, Australia, New Zealand); AFRICA (Ethiopia, Malawi) (Ţura et al., 2011).

Distribution in Russia: see Tables 1,2 .

Cultural characteristics: Nobles (1965); Westhuizen (1971).

N o te: In the field, the species can be easily identified due to smoke or mouse-gray hymenial fields with white-cream sterile border, by small pores 6-7 per $\mathrm{mm}$, and black line above the hymenophore. Some variants of $B$. fumosa can come nearer to the discussed species, but they are easily separated by more obscure dense zone of cinnamomeous colors and (in median) larger pores which are as a rule anisodiametric. After wintering, its blackish-gray hymenophore can change the color to coffeate (resembling those of $B$. fumosa), but in this state white reticulum (glacing tube moths) absent and pores in median stay sufficiently smaller.

The variability of the species concerns mode of growth organization and the degree of tubes development. A lot of forms were described during species history and the basic ones are described below.

Forma resupinata (Bourdot et Galzin) Domański, Orloś et Skirg., 1967, Flora Polska, Grzyby (Mycota), Aphyllophorales: 114. - Leptoporus adustus f. resupinatus Bourdot et Galzin, 1928 (“1927”) Hyménomyc. France (Sceaux): 552.

Basidiocarps as resupinate patches 3-10 and more $\mathrm{cm}$ in diam. with well-developed mucedinous margin. The hymenophore is well-developed, but pores can be locally enlarged at $2-5$ per mm (Bondartsev, 1953). The micromorphology varies as in a neutral type. This is prostrate growth form of the fungus known on many hardwoods.

Forma tegumentosa (Velen.) Bondartsev, 1953, Tinder Fungi Europ. U.S.S.R. Caucasus: 240. Polyporus tegumentosus Velen., 1925, Mykologia (Prague), 2: 74 (see fig. 3).

Basidiocarps as decurrent to resupinate prostrating pilei $4-6 \mathrm{~cm}$ in the largest dimension with- 


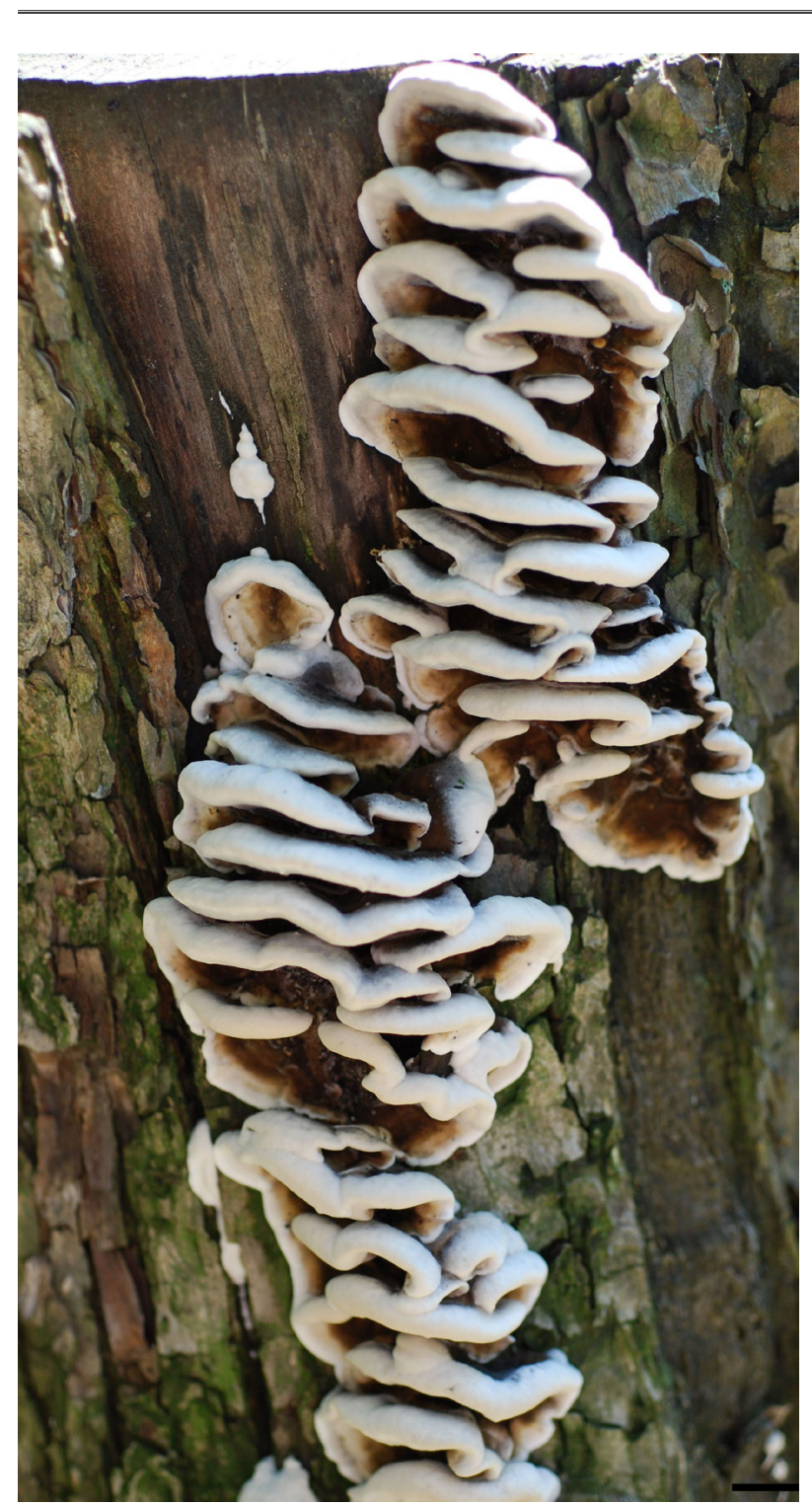

Fig. 1. The most widespread («effused-reflexed») morphotype of Bjerkandera adusta presented by clustering pilei, developing from a common effused "stroma". Scale bar $-1 \mathrm{~cm}$.

out a hymenophore. A central fields of the patches ochraceous-gray, or mouse-gray, margin white. The fungus resembles a stromata of pyrenomycete Kretzschmaria deusta (Hoffm.) P. M. D. Martin. The micromorphology varies as in a neutral type. This is sterile and more or less prostrate, but negatively geotropic (with upward subhymenial filed) growth form of the fungus known on many hardwoods.

Ep it y pe: Russia, Saint Petersburg, "Literatorskie mostki" museum necropolis, on stump of Acer platanoides, 12 VII 2015, leg. et det. I. V. Zmitrovich (LE 287571).

Basidiocarps $2.1 \times 1.5 \times 0.05-0.2 \mathrm{~cm}$, wrinkled due to basidiocarp initial centers, prostrate with inrolling undulating margin and centrally sterile (teg-
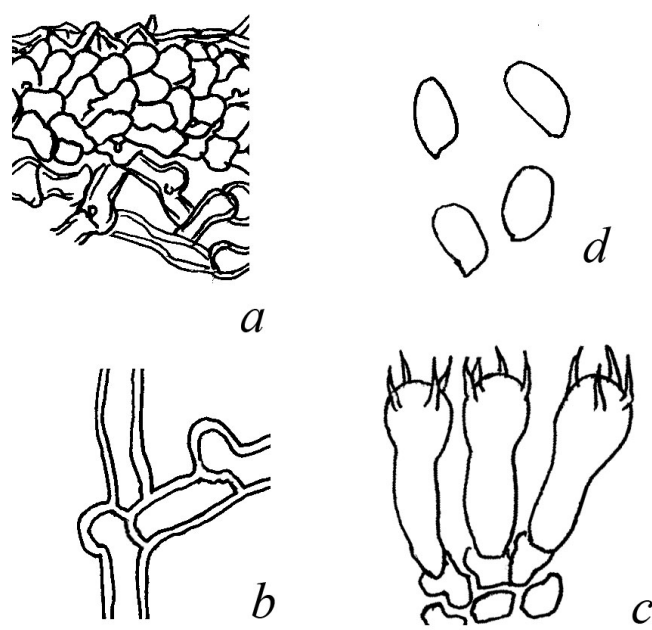

Fig. 2. The microstructures of Bjerkandera adusta: $a-$ the hyphal structure of a sterile colored «tegument» (f. tegumentosa, LE 287571), $b$ - a typical hystion, composing a sterile tissues of the fungus, $c$ - basidia, $d$ - basidiospores. Scale bar $-5 \mu \mathrm{m}$.

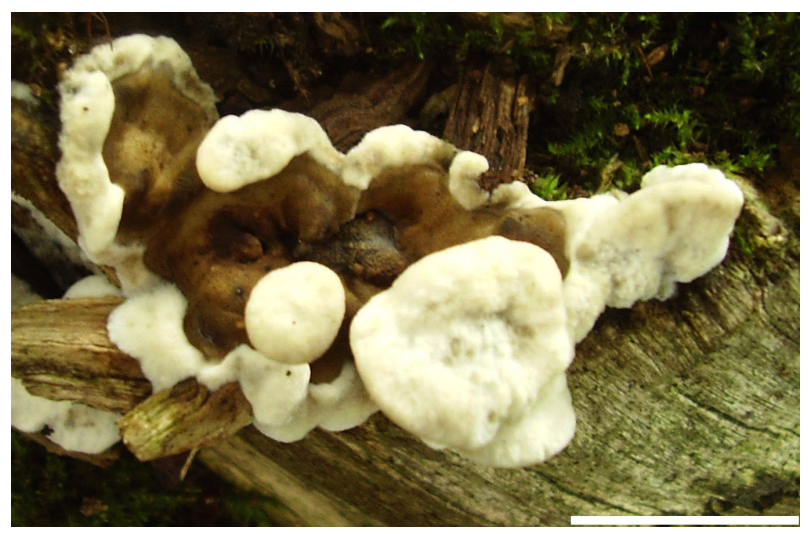

Fig. 3. Bjerkandera adusta f. tegumentosa (LE 287571), growing in a natural conditions. Scale $\mathrm{bar}-1 \mathrm{~cm}$.

umentose) negatively geotropic subhymenial fields of isabelline, then mouse-gray coloration. On marginal areas under lens can be allocated whitish net with cellars 7-10 per mm and ca. $0.1 \mathrm{~mm}$ deep. The micromorphology varies as in a neutral type. The tegument structure is pictured in fig. $2 a$. Basidia and basidiospores not developed.

Forma solubilis (Velen.) (Velen.) Bondartsev, 1953, Tinder Fungi Europ. U.S.S.R. Caucasus: 239. - Daedalea solubilis Velen., 1926, Mykologia (Prague), 3: 102.

Basidiocarps as easily separated from substrate dorsally attached resupinate patches $2-4 \mathrm{~cm}$ in diam. with well-developed bolster-like margin. The pores of normal sizes, but of daedaleoid appearance, 
smoky-gray. The micromorphology varies as in a neutral type. This is resupinate growth form of the fungus which has a certainly disordered hymenophore. Known on hardwoods.

Exsiccates examined. F. O. Westerberg "Flora Suecica", no. 10, Sweden, 6 X 1912, leg. F. O. Westerberg (ut Polyporus stereoides), det. A. S. Bondartsev. - J. Lütkemüller "Kryptogamae exsiccatae, no. 308, Austria, on dry trunk in the garden (ut Polyporus adustus). - A. de Mágócst-Dietz "Kryptogamae exsiccatae", no. 308b: Hungaria, Budapest, Botanical garden, trunk of Ailanthus glandulosa (ut Polyporus adustus). - "Farlow Herbarium" distr. Harvard Univ., "California Fungi“ distr. Herb. Univ. California, no. 246, Los Gatos canyon, on Alnus rubra, 23 II 1924, leg. H. E. Parks (ut Polyporus adustus). - V. Litschauer et H. Lohwag "Fungi selecti exiccati europaei", no. 121: Austria, Wien, Botanical garden, on dry Fagus sylvatica, 12 VII 1929, leg. V. Litschauer (ut Poria canescens P. Karst.), det. A. S. Bondartsev ut Bjerkandera adusta f. resupinata. E. Leppik "Fungi Estonici exsiccati, fasc. 1", no. 18, Tartumaa, on fallen Populus tremula, 15 VI 1930, leg. E. Leppik (ut Leptoporus adustus); ibid., no. 19, Tartu, Botanical garden, on drying Aesculus hippocastanum, 6 VII 1930, leg. E. Leppik (ut Leptoporus adustus). - S. Lundell et J. A. Nannfeldt "Fungi Exsiccati Suecici, Praesertim Upsaliensis", no. 57, Upland, Uppsala, Carolinapark, on stumps of frondose tree, 8 VII 1933, leg. S. Lundell (ut Polyporus adustus). - K. E. Murashkinsky "Hymenomycetes Sibiriae", Kazakhstan, Borovoye, on Sambucus, I 1936 (ut Coriolus adustus f. resupinatus). - S. Lundell et J. A. Nannfeldt "Fungi Exsiccati Suecici, Praesertim Upsaliensis", no. 2616, Gästrikland, Gävle, Vallshage, on dead trunk of Sambucus racemosa, 21 VIII 1956, leg. J. A. Nannfeldt (ut Polyporus adustus). - "Plantae Norvegicae" distr. Mus. Bot. Univ. Oslo, no. 95, Lyngdal, on Tilia cordata, 26 IX 1969, leg. L. Ryvarden. - "Herbier National de Mycologie du Canada", no. GCF 26, Quebec, Gatineau park, on wood, X 1979, leg. N. Binyamini. - "Fungi Rossici" distr. Mus. Bot. Univ. Helsinki, no. 2, Karelia, Vodlozero Nat. Park, on Populus tremula/Phellinis tremulae, 23 VIII 1994, leg. R. Penttilä. - "Fungi Rossici" distr. Mus. Bot. Univ. Helsinki, no. 36, Karelia, Vodlozero Nat. Park, on Populus tremula, 25 VIII 1994, leg. R. Penttilä.

2. Bjerkandera fumosa (Pers.: Fr.) P. Karst., 1879, Medd. Soc. Fauna Fl. Fenn. 5: 38. $\equiv$ Boletus fumosus Pers., 1801, Syn. Meth. Fung., 2: 530. Polyporus fumosus Pers.: Fr., 1821, Syst. Mycol.,
1: 363. - Gloeoporus fumosus (Pers.: Fr.) Pilát in Kavina et Pilát, 1937, Atlas Champ. Eur., 3: 149. Tyromyces fumosus (Pers.: Fr.) Pouzar, 1966, Folia Geobot. Phytotax. Bohemoslov., 1: 370. - Polystictoides fumosus (Pers.: Fr.) Teixeira, 1986, Rev. Brasil. Bot., 9, 1: 43. - Grifola fumosa (Pers.: Fr.) Zmitr. et Malysheva in Zmitr., Malysheva et Spirin, 2006, Mycena, 6: 21.

= Boletus imberbis Bull., 1791, Hist. Champ. France, 10: 339.

= Daedalea saligna Fr., 1818, Observ. Mycol., 2: 241.

= Polyporus pallescens Fr., 1818, Observ. Mycol., 2: 256.

$=P$. demissus Berk., 1845, London J. Bot., 4: 345.

= P. salignus var. holmiensis Fr., 1874, Hymenomyc. Eur.: 544.

$=$ P. fragrans Peck, 1878, (“1877”), Ann. Rep. N. Y. St. Mus. Nat. Hist., 30: 45.

= Bjerkandera pallescens subsp. pura P. Karst., 1882, Medd. Soc. Fauna Fl. Fenn., 9: 69.

= Polyporus hederae Ade, 1911, Mitt. Bayer. Bot. Ges., 2: 371.

$=P$. decurrens Velen., 1922, České Houby, 4-5: 657.

$=P$. emergens Velen., 1922, ibid.: 657.

$=P$. eminens Velen., 1922, ibid.: 639 .

P. robiniae Velen., 1922, ibid.: 658.

P. tyttlianus Velen., 1922, ibid.: 686.

P. aberrans Velen., 1925, Mykologia (Prague), 2, 5: 73 .

I c o n.: Sowerby (1799: tab. 230, ut Boletus pelloporus); Bulliard (1798: tab. 445, ut Boletus imberbis); Breitenbach, Kränzlin (1986: fig. 330); Gilbertson, Ryvarden (1986: fig. 66); Ryvarden, Gilbertson (1993: fig. 73); Roy, De (1996: fig. 14); Bernicchia (2005: fig. 141; pl. p. 611); Niemelä (2005: fig. 54); Jung et al. (2014: fig. 1B); Ryvarden, Melo (2014: fig. 77).

Basidiocarps $1-7 \times 1.5-10 \times 0.3-2 \mathrm{~cm}$, annual (wintering), as sessile, decurrent or subresupinate clustering pilei of tough-fleshy consistency. Upperside tomentose to matt or appressedly hispidsquamulose, whitish, pale-cream to isabelline, or tan, sometimes with cinnamomeous obscure median zone, rather loose and spongy. The margin more or less obtuse, border-like on resupinate parts, slightly undulating, white-cream, then with isabelline and cinnamomeous shades, sterile up to $2 \mathrm{~mm}$ at the maturity. Context with anise odor when fresh, two-layered with buff soft fibrous upper layer $0.3-1.5 \mathrm{~cm}$ thick and dense brownish-cinnamon layer above the 
hymenophore. Hymenophore as a single tube layer $0.02-0.7 \mathrm{~cm}$ thick of ceraceous consistency, initially cream, then tan to coffeate. Pores (1)2-4(5) per mm, round or angular, isodiametric or anisodiametric; pore surface combines whitish, cream or yellowish (tube mouths) and buff to isabelline (pore substructure) tinges (fig. 4).

Hyphal system monomitic in the tubes and pseudodimitic in context. Generative hyphae $2.5-4.5 \mu \mathrm{m}$ in diam., regularly branched at acute margin, with regular clamp connections. Pseudoskeletal hyphae $3.2-7(12) \mu \mathrm{m}$ in diam., fibrous or ramified, thickwalled to subsolid in $\mathrm{KOH}$, in some parts swelling at $12 \mu \mathrm{m}$ in cross. Cystidia none. Basidia 19-23 $\times$ 4.5-7 $\mu \mathrm{m}$, clavate with median constriction, 4-spored, with a basal clamp. Basidiospores 5.5-7.2 $\times$ 2.5-3.7 $\mu \mathrm{m}$, ellipsoid-cylindric, smooth, thinwalled, negative in Melzer's reagent (fig. 5).

On dying trees, fallen logs and branches, stumps, buried wood and small debris of many hardwoods, causing a white rot. For pathogenic significance see Bondartsev (1924).

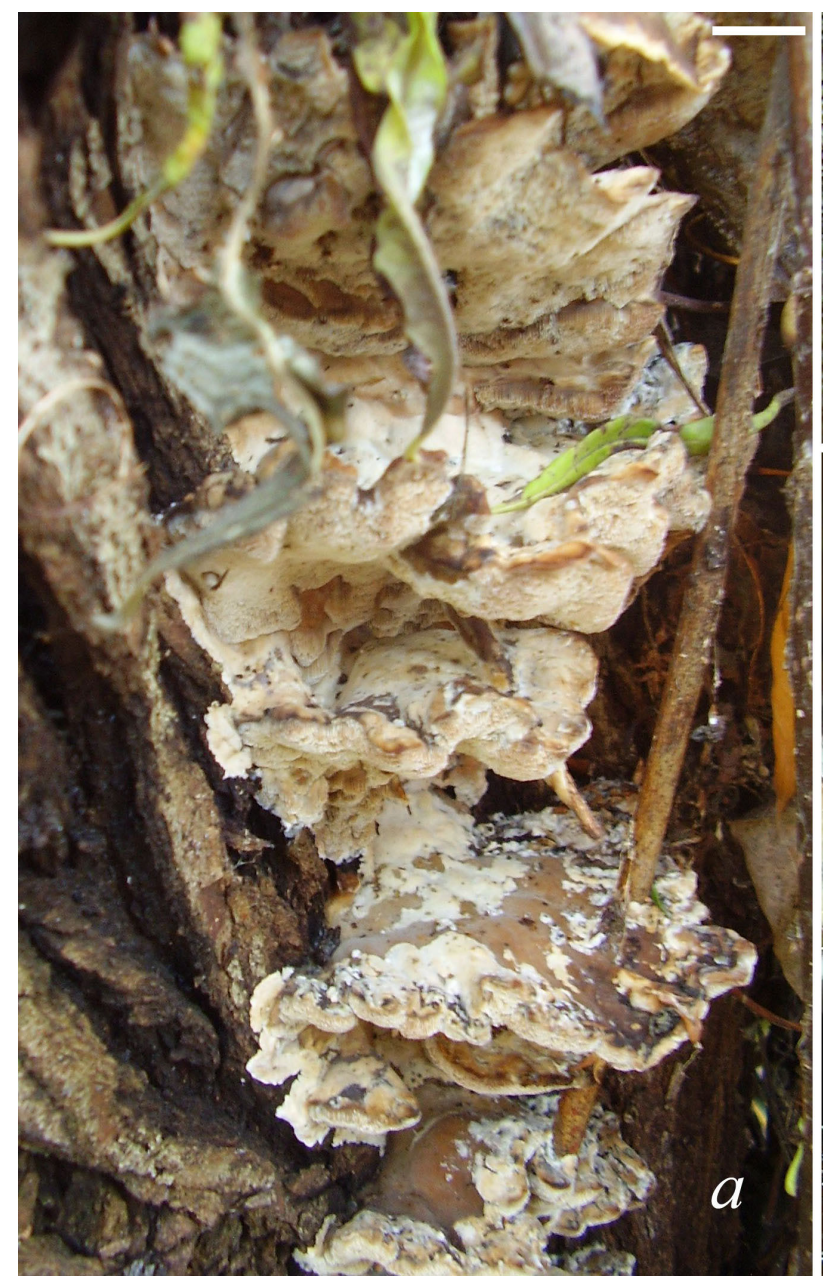

Substrata: Acer, Aesculus, Ailanthus, Alnus, Betula, Corylus, Cytisus, Eucalyptus, Fagus, Fraxinus, Juglans, Malus, Myoporum, Philadelphus, Populus, Prunus, Quercus, Salix, Sambucus, Sorbus, Tilia, Ulmus (Ryvarden, Melo, 2014), Cedrus deodara (Roy, De, 1996).

General distribution: EUROPE (Austria, Belarus, Belgium, Bulgaria, Czech Republic, Denmark, Estonia, Finland, France, Georgia, Germany, Hungary, Italy, Latvia, Lithuania, the Netherlands, Norway, Poland, Romania, Russia, Slovakia, Sweden, Switzerland, Ukraine, United Kingdom), NORTH AMERICA (Canada, USA), ASIA (China, India, Kazakhstan, Russia, Thailand, Uzbekistan), NORTH AFRICA (Bondartsev, 1953; Gilbertson, Ryvarden, 1986; Ryvarden, Gilbertson, 1993; Roy, De, 1996; Bondartseva, 1998).

Distribution in Russia: see Tables 3, 4.

Cultural characteristics: Nobles (1965).

Note: This is rather variable species, easily recognized by two-layered context with obscure lower dense strate and strongly developed whitish reticu-

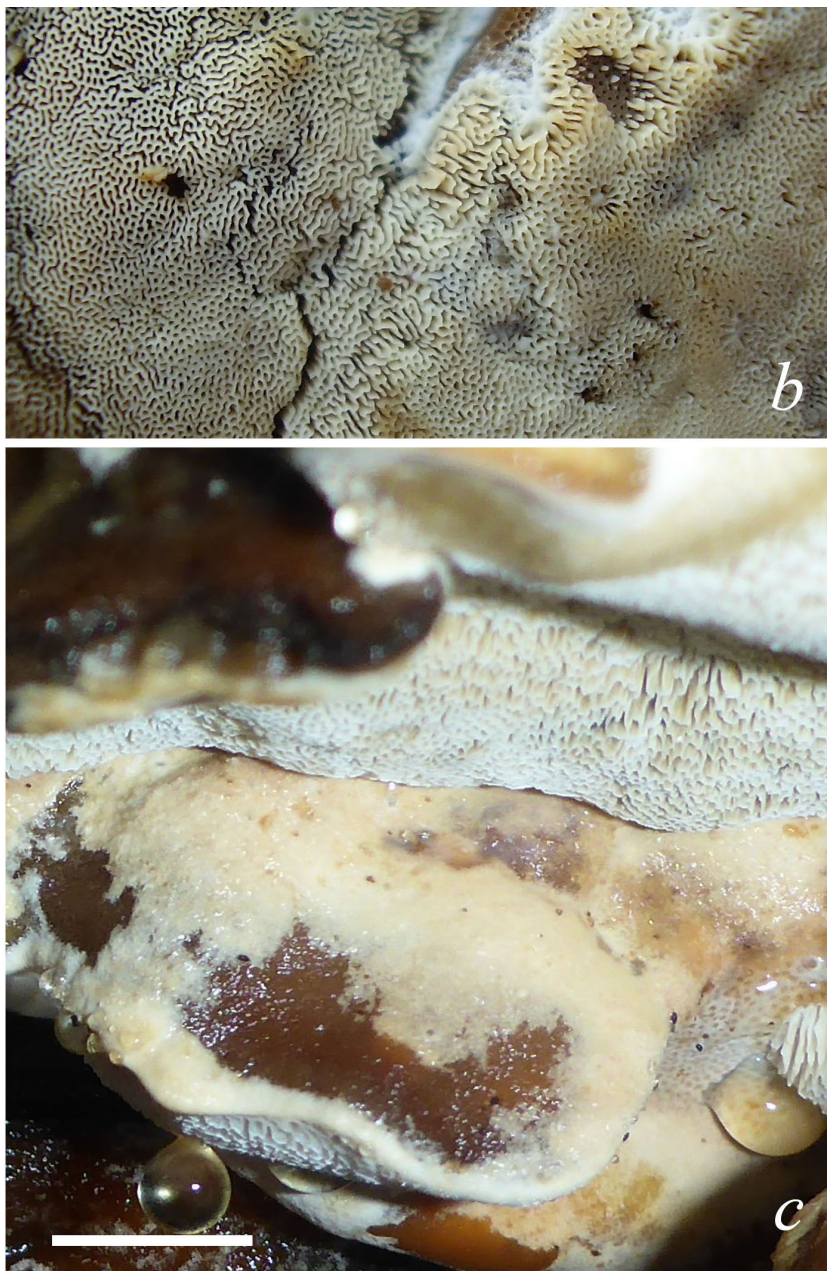

Fig. 4. The most widespread («imbricate») ecotype of Bjerkandera fumosa presented by clustering pilei, developing from a common «stroma», deeply rooted into substrate (Salix fragilis): $a$ - a general view, $b$ - pore surface with labyrinthine areas, $c$ - wintered basidiocarps. Scale bar: $a-10 \mathrm{~mm}, b, c-5 \mathrm{~mm}$. 

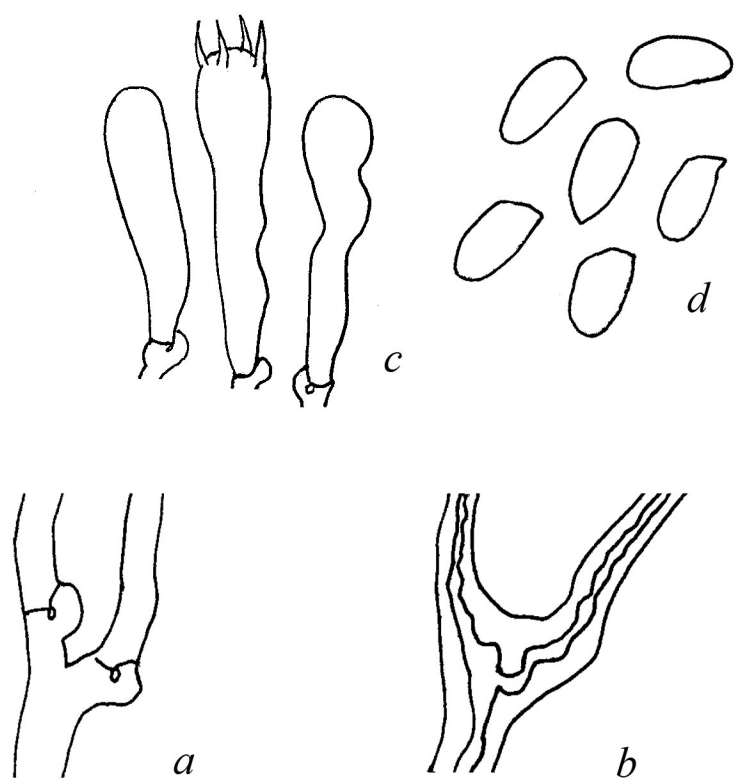

Fig. 5. The microstructures of Bjerkandera fumosa: $a-\mathrm{a}$ typical hystion, composing the subhymenium, $b-$ a typical hystion, composing the context, $c$ - basidia, $d$ - basidiospores. Scale bar $-5 \mu \mathrm{m}$.

lum over tube moths. In some cases, the hymenophore looks to be whitish-cream without deep coloration, but usually tan or coffeate shades are well expressed. The cap clusters reminiscent those of $B$. adusta, but two species easily distinguishable due to diverse pore shape and sizes, coloration of the context and hymenophoral fields. B. fumosa has typically more thick basidiocarps with more or less obtuse margin and haven't a mouse-gray tinges in the hymenophore coloration. The coffeate wintered specimens of $B$. adusta differs by smaller pores (6-7 per $\mathrm{mm}$ vs. 1-5 per $\mathrm{mm}$ in $B$. fumosa) and dense ceraceous black line above the tube (dense zone in $B . f u$ mosa is looser and of cinnamomeous color). Several chromatic and growth forms were described during species history, the basic ones are listed below.

Forma flavipora (Bourdot et Galzin) Zmitr. et Bondartseva, comb. nov. (MB 813429). - Leptoporus imberbis f. flaviporus Bourdot et Galzin, 1925, Bull. trimest. Soc. mycol. France, 41, 1: 131 (see fig. 6).

As a neutral type, but with yellowish-cream to lemon-yellow pore surface without a coffeate substructure.

Epitype: Russia, Saint Petersburg, Botanical garden of the Komarov Botanical Institute, on drying Sorbus aucuparia, 15 IX 2014, leg. \& det. I. V. Zmitrovich (LE 287572).

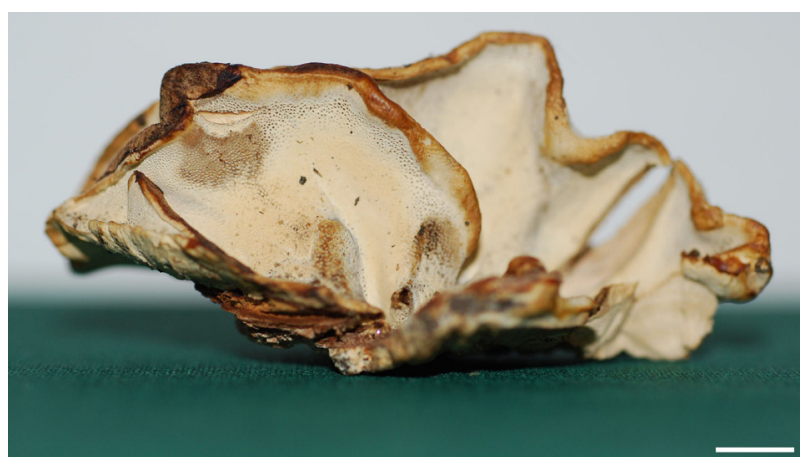

Fig. 6. Bjerkandera fumosa f. flavipora (LE 287572). Scale bar $-5 \mathrm{~mm}$.

Basidiocarps $4.5 \times 2.5 \times 1.7 \mathrm{~cm}$, as sessile decurrent clustering pilei of tough-fleshy consistency. Upperside tomentose, slightly scrupose, pale-cream with isabelline margin, rather loose and spongy. The margin more or less obtuse, undulating, isabelline $2.5 \mathrm{~mm}$. Context two-layered with buff soft fibrous upper layer $\sim 1.3 \mathrm{~cm}$ thick with weak coffeate streak above the hymenophore. Hymenophore as a single tube layer $\sim 0.05 \mathrm{~cm}$ thick, of ceraceous consistency, buff in section. Pores 3-4 per mm, angular and anisodiametric; pore surface yellowish-cream. The micromorphology varies as in a neutral type. Basidiospores 5.5-6.5 × 2.5-3.0 $\mu \mathrm{m}$.

Forma saligna (Fr.) Donk, 1933, Med. Bot. Mus. Univ. Utrecht, 9: 164. - Polyporus salignus Fr., 1838, Epicr.: 452.

As a neutral type with decurrent base of cap clusters, daedaleoid pores and almost white upperside. Known on Salix sp. in the Netherlands, Sweden, Belarus and Orel Region of the Russia (Donk, 1933; Bondartsev, 1953).

Forma alba (Huds.) Donk, 1933, Med. Bot. Mus. Univ. Utrecht, 9: 164. - Boletus albus Huds., 1762, Fl. Angl.: 626.

Resembling the previous form, but with sessile (not decurrent) caps with more intensively colored uppeside. Known on Salix sp. in the Netherlands, France and Sweden (Donk, 1933).

Exsiccates examined. L. Romell "Fungi Exsiccati Praesertim Scandinavici", no. 11, Sweden, Holm, on trunk of Quercus sp., 24 XI 1889, leg. L. Romell (ut Polyporus holmensis). - "Terek District Station of Plant Protection" (dupl. herbarium), no. 634, on stumps of Juglans regia, 25 X 1926, leg. A. Lobik (ut Polyporus imberbis). - J. Smarods "Fungi Latvici", Vidzeme, on Fraxinus excelsior, 19 XI 1935, leg. J. Smarods. - E. Leppik, V. Litschauer "Fungi Estonici" (Mycotheca Lab. Phytopath. Univ. Tartuensis), dupl., on fallen trunk of Sambucus nigra, 9 XI 1939, leg. E. Leppik (ut Septoporus imber- 
bis). - S. Lundell et J.A. Nannfeldt "Fungi Exsiccati Suecici, Praesertim Upsalienses", no. 440, Upland, Bondkyrka parish, on stump of Populus tremula (?), 28 IX 1935, leg. S. Lundell (ut Polyporus fumosus). - A. Jones "Mycological Collections" distr. Herb. Univ Illinois, no. 95, on dead Ulmus sp., 22 XI 1959, leg. A. Jones (ut Polyporus fumosus). - A. Jones "Mycological Collections" distr. Herb. Univ Illinois, no. 157, on dead Ulmus sp., 13 XI 1960, leg. A. Jones (ut Polyporus fumosus). S. Lundell, J.A. Nannfeldt et L. Holm "Fungi Exsiccati Suecici, Praesertim Upsalienses", no. 3088, Västmaland, Norberg, on stump of Ulmus glabra, 27 VIII 1963, leg. I. Nordin.

Apart from aforementioned species, Murrill (1907) gives two additional descriptions which hardly correlated to any known taxa. Their diagnoses are presented below.

Bjerkandera terebrans (Berk. et M. A. Curtis) Murrill, 1907, N. Amer. Fl., 9, 1: 42. $\equiv$ Polyporus terebrans Berk. et M. A. Curtis, 1869 ("1868"), J. Linn. Soc. Bot., 10: 306.

"Pileus subfleshy, thick, flabelliform, convex, $4 \times$ 4-5 $\times 1 \mathrm{~cm}$, attached by a thick, laterally-compressed, concolorous, pubescent elongation resembling a stipe, but probably the result of an effort of the part of sporophore to escape from the substratum; surface isabelline to luteous, pubescent-scabrous, azonate, smooth; margin obtuse, entire: context white to isabelline, homogeneous, soft-corky, nearly $1 \mathrm{~cm}$ thick; tubes whitish when young, fuliginous in dried specimens, less than $1 \mathrm{~mm}$, mouths 4 to a mm, edges obtuse, entire. Spores not examined" (Murrill, 1907).

Type locality: Cuba (without exact region indication).
Substrata: on dead trees.

Distribution: known only from the type locality.

It is probably a certain form of $B$. fumosa, but stipe-like base not allow to reject also possibility of variant of Osteina obducta (Berk.) Donk.

Bjerkandera subsimulans (Berk. et M. A. Curtis) Murrill, 1907, N. Amer. Fl., 9, 1: 42. $\equiv$ Polyporus simulans Berk. et M. A. Curtis in Sacc., 1888, Syll. Fung., 6: 117; nec Bjerkandera simulans P. Karst., 1888, Rev. Mycol., 10, 37: 73 = Postia tephroleuca (Fr.) Jülich, 1982.

"Pileus explanate, fleshy-tough, sessile, dimidiate of fan-shaped, often attached by a narrow base, $5-10 \times 10-15 \times 0.3-0.7 \mathrm{~cm}$, surface smooth, partially glabrous and partially clothed with scanty, flexible hairs; margin thin, acute, broadly sterile, lobed, with a zone of appressed hairs and blackish as tough scorched for 5-10 mm: context fibrous, hard and corky when dry, white to isabelline; tubes $2-5 \mathrm{~mm}$ long, white to fuliginous, mouths angular, irregular, 1 to $3 \mathrm{a} \mathrm{mm}$, edges thin. Spores not examined" (Murrill, 1907).

Type locality: Cuba (without exact region indication).

Substrata: dead trunks.

Distribution: known only from the type locality.

This superficial description corresponds in a certain respects to Abortiporus biennis (Bull.) Singer.

This work was carried out in the Laboratory of Systematics and Geography of Fungi of the Komarov Botanical Institute of the Russian Academy of Sciences in canvas of the State task N 01201255602.

Table 1

\section{Herbarium data on distribution of Bjerkandera adusta over Russia territory and its substrate preferences}

\begin{tabular}{l|c|c|c|c}
\hline \multicolumn{1}{c|}{ Region } & Substrata & $\begin{array}{c}\text { Date of } \\
\text { collection }\end{array}$ & Collector & $\begin{array}{c}\text { Herbarium } \\
\text { numbers }\end{array}$ \\
\hline \multicolumn{4}{|c|}{ European part } \\
\hline $\begin{array}{l}\text { Bryansk Region, } \\
\text { Bryansk vic. }\end{array}$ & Fraxinus excelsior & VII 1907 & A. S. Bondartsev & LE 26254 \\
\hline $\begin{array}{l}\text { Kaliningrad Region, } \\
\text { Golubaya river }\end{array}$ & - & 25 VI 2010 & V. M. Kotkova & LE 268941 \\
\hline $\begin{array}{l}\text { Kaluga Region, Kaluga } \\
\text { vic. }\end{array}$ & Salix sp. & 10 X 1909 & Chernyshov & LE 26141 \\
\hline $\begin{array}{l}\text { Kaluga Region, Ugra } \\
\text { National Park }\end{array}$ & Fraxinus excelsior & 28 VII 2013 & S. V. Volobuev & LE 299084 \\
\hline $\begin{array}{l}\text { Karelia Republic, Lakh- } \\
\text { denpokhja }\end{array}$ & Betula sp. & 10 X 1950 & A. S. Bondartsev & LE 26286 \\
\hline
\end{tabular}


Continuation of Table 1

\begin{tabular}{|c|c|c|c|c|}
\hline Region & Substrata & $\begin{array}{c}\text { Date of } \\
\text { collection }\end{array}$ & Collector & $\begin{array}{c}\text { Herbarium } \\
\text { numbers }\end{array}$ \\
\hline Karelia Republic & Populus tremula & 20 IX 1995 & V. M. Lositskaya & LE 85364 \\
\hline $\begin{array}{l}\text { Karelia Republic, } \\
\text { Matrosy }\end{array}$ & Populus tremula & & V. M. Kotkova & LE 203909 \\
\hline Kursk Region, Kursk & timber wood & 1907 & A. S. Bondartsev & LE 26191 \\
\hline Kursk region, Korochi & Acer sp. & 28 VIII 1945 & L. A. Lebedeva & LE 26219 \\
\hline $\begin{array}{l}\text { Leningrad Region, } \\
\text { Nadevitsy }\end{array}$ & Betula sp. & 31 VII 1932 & T. L. Nikolaeva & LE 26255 \\
\hline $\begin{array}{l}\text { Leningrad Region, } \\
\text { Siverskaya }\end{array}$ & Picea abies & 4 VII 1936 & R. Singer & LE 26189 \\
\hline $\begin{array}{l}\text { Leningrad Region, } \\
\text { Yanega }\end{array}$ & Populus tremula & 19 IX 1961 & M. A. Bondartseva & LE 26212 \\
\hline $\begin{array}{l}\text { Leningrad Region, } \\
\text { Berezovye Ostrova pro- } \\
\text { tected area }\end{array}$ & Populus tremula & 23 VII 2003 & V. M. Kotkova & LE 242293 \\
\hline $\begin{array}{l}\text { Leningrad Region, } \\
\text { Berezovye Ostrova pro- } \\
\text { tected area }\end{array}$ & $\begin{array}{l}\text { Alnus incanal } \\
\text { Gloeoporus dichrous }\end{array}$ & 8 VII 2004 & V. M. Kotkova & LE 268485 \\
\hline $\begin{array}{l}\text { Leningrad Region, } \\
\text { Cheremenetskiy pro- } \\
\text { tected area }\end{array}$ & Populus tremula & 7 IX 2002 & V. M. Kotkova & LE 283875 \\
\hline $\begin{array}{l}\text { Leningrad Region, Kur- } \\
\text { galsky protected area }\end{array}$ & Populus tremula & 11 IX 1997 & I. V. Zmitrovich & LE 203484 \\
\hline $\begin{array}{l}\text { Leningrad Region, Kur- } \\
\text { galsky protected area }\end{array}$ & Quercus robur & 12 IX 1997 & I. V. Zmitrovich & LE 203408 \\
\hline $\begin{array}{l}\text { Mari El, Kuvshin for- } \\
\text { estry }\end{array}$ & - & 20 VII 1937 & B. P. Vassilkov & LE 26258 \\
\hline $\begin{array}{l}\text { Moscow Region, Push- } \\
\text { kino }\end{array}$ & Betula sp. & 27 VIII ? & A. S. Bondartsev & LE 26248 \\
\hline $\begin{array}{l}\text { Moscow Region, } \\
\text { Mikhailovskoye }\end{array}$ & Populus tremula & $1 \mathrm{~V} 1907$ & A. S. Bondartsev & LE 26164 \\
\hline $\begin{array}{l}\text { Moscow Region, Goro- } \\
\text { dishche }\end{array}$ & Populus sp. & 20 IX 2008 & N. V. Psurtseva & LE 265214 \\
\hline Nizhegorod Region & $\begin{array}{c}\text { Pinus sylvestris cones/ } \\
\text { litter }\end{array}$ & 5 VIII 1997 & W. A. Spirin & LE 208432 \\
\hline $\begin{array}{l}\text { Orel Region, Lov- } \\
\text { chikovo }\end{array}$ & Tilia cordata & 1 VIII 2011 & S. V. Volobuev & LE 298944 \\
\hline Orel Region, Turovka & Corylus avellana & 11 VIII 2012 & S. V. Volobuev & LE 298777 \\
\hline Orel Region, Naryshkino & Populus tremula & $6 \times 2012$ & S. V. Volobuev & LE 291153 \\
\hline $\begin{array}{l}\text { Rostov Region, Rostov- } \\
\text { on-Don }\end{array}$ & Betula pendula & 15 V 2009 & Yu. A. Rebriev & LE 287095 \\
\hline $\begin{array}{l}\text { Saint Petersburg, Botani- } \\
\text { cal Garden of Komarov } \\
\text { Botanical Institute }\end{array}$ & - & VIII 1908 & A. S. Bondartsev & LE 26147 \\
\hline $\begin{array}{l}\text { Tver Region, Tsentralno- } \\
\text { Lesnoi reserve }\end{array}$ & Betula sp. & 5 IX 2011 & V. M. Kotkova & LE 284240 \\
\hline Tula Region, Tula vic. & timber wood & 1911 & Trusova & LE 26203 \\
\hline $\begin{array}{l}\text { Udmurtia Republic, } \\
\text { Izhevsk vic. }\end{array}$ & Tilia cordata & 15 IX 1964 & Kyganova & LE 26237 \\
\hline \multicolumn{5}{|c|}{ Caucasia } \\
\hline Chechen Republic, Terek & Vitis sp. & $20 \mathrm{~V} 1926$ & L. Guseva & LE 26079 \\
\hline $\begin{array}{l}\text { Chechen Republic, } \\
\text { Naurskaya }\end{array}$ & - & $20 \mathrm{~V} 1926$ & L. Guseva & LE 26181 \\
\hline
\end{tabular}


End of Table 1

\begin{tabular}{|c|c|c|c|c|}
\hline Region & Substrata & $\begin{array}{c}\text { Date of } \\
\text { collection }\end{array}$ & Collector & $\begin{array}{c}\text { Herbarium } \\
\text { numbers }\end{array}$ \\
\hline $\begin{array}{l}\text { Karachaevo-Cherkessia } \\
\text { Republic, Teberda } \\
\text { reserve }\end{array}$ & Carpinus betulus & 19 VIII 2012 & N. V. Psurtseva & LE 288328 \\
\hline $\begin{array}{l}\text { Stavropol Territory, } \\
\text { Pyatigorsk }\end{array}$ & Fagus sylvatica & 12 IX 1926 & A. Lobik & LE 26257 \\
\hline $\begin{array}{l}\text { Stavropol Territory, } \\
\text { Zheleznovodsk }\end{array}$ & Fagus sylvatica & 13 VII 1926 & G. Lagadidze & LE 26234 \\
\hline \multicolumn{5}{|c|}{ Siberia } \\
\hline $\begin{array}{l}\text { Gorno-Altai } \\
\text { Autonomous Republic, } \\
\text { Kaitanak }\end{array}$ & Betula sp. & 19 VII 1968 & M. A. Bondartseva & LE $26146 / 162$ \\
\hline $\begin{array}{l}\text { Gorno-Altai Autono- } \\
\text { mous Republic, Kaita- } \\
\text { nak }\end{array}$ & Salix sp. & 19 VII 1968 & M. A. Bondartseva & LE 26156 \\
\hline Irkutsk Region, Orlenga & Betula sp. & 2 IX 1967 & M. A. Bondartseva & LE $26167 / 68$ \\
\hline $\begin{array}{l}\text { Irkutsk Region, Irkutsk } \\
\text { vic. }\end{array}$ & - & 26 VIII 1911 & Alexandrov & LE 26166 \\
\hline $\begin{array}{l}\text { Krasnoyarsk Territory, } \\
\text { Monastyrskoye }\end{array}$ & Betula sp. & 28 VI 1920 & A. L. Yavorskiy & LE $26179 / 190$ \\
\hline $\begin{array}{l}\text { Krasnoyarsk Territory, } \\
\text { Stolby }\end{array}$ & Betula sp. & 8 XI 1968 & M. A. Bondartseva & LE 26152 \\
\hline \multicolumn{5}{|c|}{ Far East } \\
\hline $\begin{array}{l}\text { Khabarovsk Territory, } \\
\text { Vinogradovka }\end{array}$ & - & XI 1929 & A. S. Bondartsev & LE 26144 \\
\hline $\begin{array}{l}\text { Khabarovsk Territory, } \\
\text { Khabarovsk vic. }\end{array}$ & Acer sp. & $9 \mathrm{~V} 1935$ & L. V. Ljubarskiy & LE 26213 \\
\hline $\begin{array}{l}\text { Khabarovsk Territory, } \\
\text { Bolshekhekhtsyrskiy } \\
\text { reserve }\end{array}$ & Betula sp./Trichaptum & 20 VIII 1979 & M. A. Bondartseva & LE 26135 \\
\hline $\begin{array}{l}\text { Khabarovsk Territory, } \\
\text { Bastak reserve }\end{array}$ & Corylus avellana & 21 VII 2011 & N. V. Bukharova & LE 290715 \\
\hline $\begin{array}{l}\text { Primorye Territory, } \\
\text { Kangauz }\end{array}$ & Carpinus sp. & 1928 & A. S. Bondartsev & LE 26184 \\
\hline
\end{tabular}

Table 2 The substrate preferences of Bjerkandera adusta in old-growth arboreta on Saint Petesburg territory

\begin{tabular}{|c|c|}
\hline Old-growth arboreta & Substrata \\
\hline $\begin{array}{l}\text { The Peter the Great Botanical } \\
\text { Garden of the Komarov Botanical } \\
\text { Institute of RAS }\end{array}$ & $\begin{array}{l}\text { Acer platanoides, Alnus incana, Amelanchier canadensis, Betula pendula, } \\
\text { Crataegus oxyacantha, Duschekia fruticosa, Fraxinus excelsior, Juglans } \\
\text { regia, Larix sibirica, Malus baccata, Phellodendron amurense, Populus alba, } \\
\text { Quercus robur, Sambucus racemosa, Salix alba, S. fragilis, Sorbus aucuparia, } \\
\text { S. intermedia, Tilia cordata, T. platyphyllos, Ulmus laevis, Ulmus scabra. }\end{array}$ \\
\hline $\begin{array}{c}\text { "Literatorskie mostki" museum } \\
\text { necropolis }\end{array}$ & $\begin{array}{l}\text { Acer platanoides, Philadelphus coronarius, Quercus robur, Sorbus aucuparia, } \\
\text { Syringa josikaea, S. vulgaris, Tilia cordata, T. platyphyllos, Ulmus scabra }\end{array}$ \\
\hline Volkovskoye cemetery & $\begin{array}{l}\text { Acer platanoides, A. negundo, Betula pendula, Fraxinus excelsior, } \\
\text { Philadelphus coronarius, Populus nigra, Quercus robur, Sorbus aucuparia, } \\
\text { Syringa josikaea, Tilia cordata, T. platyphyllos, Ulmus laevis, U. scabra }\end{array}$ \\
\hline $\begin{array}{l}\text { The dendrarium of the Kirov } \\
\text { Forest Management Academy }\end{array}$ & $\begin{array}{l}\text { Acer platanoides, Alnus glutinosa, Corylus avellana, Crataegus sanguinea, } \\
\text { Fraxinus excelsior, Malus baccata, Salix fragilis, Sorbus aucuparia, Tilia } \\
\text { cordata, Ulmus laevis. }\end{array}$ \\
\hline
\end{tabular}




\section{Herbarium data on distribution of Bjerkandera fumosa over Russia territory and its substrate preferences}

\begin{tabular}{|c|c|c|c|c|}
\hline Region & Substrata & Date of collection & Collector & $\begin{array}{c}\text { Herbarium } \\
\text { numbers }\end{array}$ \\
\hline \multicolumn{5}{|c|}{ European part } \\
\hline $\begin{array}{l}\text { Bryansk Region, } \\
\text { Bryansk }\end{array}$ & Betula sp. & 20 VII 1908 & A. S. Bondartsev & LE 26325 \\
\hline $\begin{array}{l}\text { Karelia Republic, } \\
\text { Sortavala forestry }\end{array}$ & Sorbus aucuparia & 21 VIII 1993 & A. V. Ruokolainen & LE 208915 \\
\hline $\begin{array}{l}\text { Kostroma Region, } \\
\text { Vasilyevka }\end{array}$ & - & 1907 & A. S. Bondartsev & LE 2635 \\
\hline Kursk Region, Kursk & Acer sp. & $25 \mathrm{~V} 1906$ & A. S. Bondartsev & LE 26318 \\
\hline $\begin{array}{l}\text { Kursk Region, Kursk, } \\
\text { Lazaretny garden }\end{array}$ & Fraxinus excelsior & 25 IX 1906 & A. S. Bondartsev & LE 26349 \\
\hline $\begin{array}{l}\text { Kursk Region, } \\
\text { Les-na-Vorskle }\end{array}$ & Betula sp. & - & I. E. Brezhnev & LE 26339 \\
\hline $\begin{array}{l}\text { Leningrad Region, } \\
\text { Nizhnesvirsky reserve }\end{array}$ & Populus tremula & 4 VIII 2014 & N. I. Kalinovskaya & LE 303809 \\
\hline $\begin{array}{l}\text { Mordovia Republic, } \\
\text { Mordovsky reserve }\end{array}$ & Ulmus glabra & 10 IX 2013 & S. Yu. Bolshakov & LE 301234 \\
\hline Moscow Region & Malus domestica & $22 \times 1984$ & M. V. Gordienko & LE 26295 \\
\hline $\begin{array}{l}\text { Orel Region, } \\
\text { Alexandrovka }\end{array}$ & Populus tremula & $5 \times 2012$ & S. V. Volobuev & LE 292076 \\
\hline Orel Region, Tureika & Quercus robur & 2 IX 2012 & S. V. Volobuev & LE 298611 \\
\hline $\begin{array}{l}\text { Rostov Region, } \\
\text { Veshenskaya }\end{array}$ & Betula sp. & $1 \times 2004$ & Yu. A. Rebriev & LE $227757 / 768$ \\
\hline $\begin{array}{l}\text { Saint Petersburg, Botani- } \\
\text { cal garden of Komarov } \\
\text { Botanical Institute }\end{array}$ & Ulmus glabra & - & A. S. Bondartsev & LE 26352 \\
\hline $\begin{array}{l}\text { Saint Petersburg, } \\
\text { Volkovskoye cemetery }\end{array}$ & Ulmus laevis & 16 IX 2003 & W. A. Spirin & LE 208178 \\
\hline $\begin{array}{l}\text { Udmurtia Republic, } \\
\text { Kigbay }\end{array}$ & Salix sp. & 5 IX 1965 & Kychanova & LE 26344 \\
\hline $\begin{array}{l}\text { Udmurtia Republic, } \\
\text { Izhevsk }\end{array}$ & Salix sp. & 9 IV 2009 & V. I. Kapitonov & LE 247363 \\
\hline \multicolumn{5}{|c|}{ Caucasia } \\
\hline $\begin{array}{l}\text { Stavropol Territory, } \\
\text { Pyatigorsk, Beshtau }\end{array}$ & Carpinus betulus & IX 1934 & A. S. Bondartsev & LE 26355 \\
\hline \multicolumn{5}{|c|}{ Urals } \\
\hline $\begin{array}{l}\text { Sverdlovsk Region, } \\
\text { Serginsky }\end{array}$ & Ulmus sp. & 18 IX 1957 & $\begin{array}{c}\text { N. T. Stepanova- } \\
\text { Kartavenko }\end{array}$ & LE 26319 \\
\hline \multicolumn{5}{|c|}{ Far East } \\
\hline $\begin{array}{l}\text { Sakhalin Territory, } \\
\text { Krasnopolye }\end{array}$ & Ulmus japonica & 31 VIII 1954 & V. N. Ljubarskiy & LE 26367 \\
\hline
\end{tabular}

Table 4 The substrate preferences of Bjerkandera fumosa in old-growth arboreta on Saint Petesburg territory

\begin{tabular}{l|l}
\hline \multicolumn{1}{c|}{ Old-growth arboreta } & Substrata \\
\hline $\begin{array}{l}\text { The Peter the Great Botani- } \\
\text { cal Garden of the Komarov } \\
\text { Botanical Institute of RAS }\end{array}$ & $\begin{array}{l}\text { Acer platanoides, Crataegus sanguinea, Malus domestica, baccata, Salix } \\
\text { fragilis, Sorbus aucuparia, S. intermedia, Tilia cordata, Ulmus laevis, U. scabra. }\end{array}$ \\
\hline $\begin{array}{l}\text { "Literatorskie mostki" } \\
\text { museum necropolis }\end{array}$ & Acer platanoides, Salix alba, Sorbus aucuparia, Syringa vulgaris, Tilia cordata \\
\hline
\end{tabular}


End of Table 4

\begin{tabular}{l|l}
\hline \multicolumn{1}{c|}{ Old-growth arboreta } & \multicolumn{1}{c}{ Substrata } \\
\hline Volkovskoye cemetery & $\begin{array}{l}\text { Acer negundo, Fraxinus excelsior, Salix alba, Sorbus aucuparia, Syringa } \\
\text { josikaea, Tilia cordata, Ulmus scabra }\end{array}$ \\
\hline & Acer platanoides, A. negundo, Alnus incana, Betula pendula, Cornus sanguinea, \\
The dendrarium of the & Crataegus sanguinea, Fraxinus excelsior, Larix sibirica, Malus baccata, Picea \\
Kirov Forest Management & glauca, Populus nigra, Quercus robur, Salix fragilis, Sambucus racemosa, \\
Academy & Sorbaria sorbifolia, Sorbus aucuparia, Syringa josikaea, Tilia cordata, \\
& T. platyphyllos, Ulmus laevis. \\
\hline
\end{tabular}

\section{REFERENCES /ЛИTEPATУPA}

Ames A. (1913) A consideration of structure in relation to genera of the Polyporaceae // Ann. Mycol. 11: 211-253.

Bernicchia A. (2005) Polyporaceae s. 1. Fungi Europaei 10: 1-808.

Binder M., Justo A., Riley R., Salamov A., Lopez-Giraldez F., Sjökvist E. (2013) Phylogenetic and phylogenomic overview of the Polyporales // Mycologia 105: 1350-1373.

Bondartsev A. S. (1924) Polyporus imberbis (Bull.) Fr. kak parazit derevyev [Polyporus imberbis (Bull.) Fr. as a parasite of trees] // Bolezni rasteniy [Plant diseases] 136: 55-59 [In Russian]. (Бондарцев A. C. Polyporus imberbis (Bull.) Fr. как паразит деревьев // Болезни растений, 1924. Т. 13. С. 55-59).

Bondartsev A. S. (1953) Tinder fungi of European part of USSR and Caucasus. Moscow - Leningrad. 1106 pp. [In Russian]. (Бондарцев A. C. Трутовые грибы Европейской части СССР и Кавказа. М.-Л., 1953. 1106 с.).

Bondartseva M. A. (1998) Definitorium fungorum Rossiae. Ordo Aphyllophorales. Fasc. 2. Familiae Albatrellaceae, Aporpiaceae, Boletopsidaceae, Bondarzewiaceae, Corticiaceae (genera tubuliferae), Fistulinaceae, Ganodermataceae, Lachnocladiaceae (genus tubiliferus), Phaeolaceae, Polyporaceae (genera tubuliferae), Poriaceae, Rigidoporaceae. Nauka, St. Petersburg, 391 pp. [In Russian]. (Бондарцева М. А. Определитель грибов России. Порядок афиллофоровые. Вып. 2: Семейства альбатрелловые, апорпиевые, болетопсиевые, бондарцевиевые, ганодермовые, кортициевые (виды с порообразным гименофором), лахнокладиевые (виды с трубчатым гименофором), полипоровые (роды с трубчатым гименофором), пориевые, ригидопоровые, феоловые, фистулиновые. СПб.: Наука, 1998. 391 с.).

Bondartseva M. A., Kotkova V. M., Zmitrovich I. V., Volobuev S. V. (2014) Aphyllophoroid and heterobasidioid fungi of the Peter the Great Botanical Garden of the Komarov Botanical Institute of RAS // Botany: history, theory, practice (to the 300-year anniversary of Komarov Botanical Institute of the Russian Academy of Sciences. St. Petersburg, pp. 23-30 [In Russian]. (Бондарцева М. А., Коткова В. М., Змитрович И. В., Волобуев С. В. Афиллофороидные и гетеробазидиальные грибы Ботанического сада Петра Великого Ботанического института им. В. Л. Комарова РАН (Санкт-Петербург) // Ботаника: история, теория, практика (к 300-летию основания Ботанического института им. В. Л. Комарова Российской академии наук): Тр. междунар. науч. конф. СПб.: Изд-во СПбГЭТУ «ЛЭТИ», 2014. С. 23-30).

Breitenbach J., Kränzlin F. (1986) Fungi of Switzerland. Vol. 2: Heterobasidiomycetes, Aphyllophorales, Gasteromycetes. Verlag Mycologia, Switzerland, $412 \mathrm{pp}$.

Brooks F. T. (1925) Polyporus adustus (Willd.) Fr. as a wound parasite of apple trees // Trans. Brit. Mycol. Soc. 10: 225-226.

Bulliard P. (1798) Herbier de la France ou collection complète des plantes indigènes de ce royaume. Paris, Pl. $1-603$.

Corner E. J. H. (1989) Ad Polyporaceas V. The genera Albatrellus, Boletopsis, Coriolopsis (dimitic). Cristelloporia, Diacanthodes, Elmerina, Fomitopsis (dimitic), Gloeoporus, Grifola, Hapalopilus, Heterobasidion, Hydnopolyporus, Ischnoderma, Loweporus, Parmastomyces, Perenniporia, Pyrofomes, Stecchericium, Trechispora, Truncospora and Tyromyces // Beih. Hova Hedwigia 96: 1-218.

Donk M. A. (1933) Revision der Niederländischen Homobasidiomycetae-Aphyllophoraceae. II // Med. Bot. Mus. Herb. Utrecht 9: 1-278.

Donk M. A. (1974) Check list of European polypores // Verh. Koninkl. Ned. Akad. Wetenschap. Nat. Reeks 62: $1-469$.

Floudas D., Hibbett D. S. (2015) Revisiting the taxonomy of Phanerochaete (Polyporales, Basidiomycota) using a four gene dataset and extensive ITS sampling // Fungal Biology 119: 1-41.

Gilbertson R. L., Ryvarden L. (1986) North American polypores. Vol. 1. Fungiflora, Oslo, 452 pp.

Jung P. E., Fong J. J., Park M. S., Oh S.-Y., Kim Ch., Lim Y. W. (2014) Sequence validation for the identification of the white-rot fungi Bjerkandera in public sequence databases // J. Microbiol. Biotechnol. 24(10): $1301-1307$. 
Karsten P. A. (1879) Rysslands, Finlands, och den Skandinaviska Halfons Hatsvamper // Medd. Soc. Fauna Fl. Fenn. 5: 1-571.

Kennedy L. L., Larcade R. J. (1971) Basidiocarp development in Polyporus adustus // Mycologia 63: 69-78.

Murrill W. A. (1903) A historical review of the genera of Polyporaceae // J. Mycol. 9: 87-102.

Murrill W. A. (1907) North American Flora. IX. Polyporaceae, 1. N. Y., pp. 1-71.

Niemelä T. (2005) Polypores, lignicolous fungi // Norrlinia 13: 1-320.

Nobles M. K. (1965) Identification of cultures of wood-inhabiting Hymenomycetes // Can. J. Bot. 43: 1097-1139.

Phillips R. (1981) Mushrooms and other fungi of Great Britain and Europe. Pan Books, London, 319 pp.

Pilát A. (1937) Polyporaceae. In: Kavina K., Pilát A. Atlás des Champignons de l'Europe. T. III, 1. Praha, 624 pp. Pouzar Z. (1966) Studies in the taxonomy of the polypores. II // Folia Geobot. Phytotax. Bohemosl. 1(4): 356-375.

Romero E., Speranza M., García-Guinea J., Martínez A. T., Martínez M. J. (2007) An anamorph of the white-rot fungus Bjerkandera adusta capable of colonizing and degrading compact disc components // FEMS Microbiol. Lett. 275: 122-129.

Rostkovius $\boldsymbol{F}$. W. (1837) Die Pilze Deutschlands I. Sturm. In: Deutschlands Flora in Abbildungen nach Natur mit Beschreibungen. Nürnberg, S. 69-100.

Roy A., De A. B. (1996) Polyporaceae of India. International book distributor, Dehra Dun, 309 pp.

Ryvarden L. (1991) Genera of polypores. Nomenclature and taxonomy // Synopsis Fung. 5: 1-363.

Ryvarden L., Gilbertson R. L. (1993) European polypores. Part 1: Abortiporus-Lindtneria. Fungiflora, Oslo, pp. $1-387$.

Ryvarden L., Melo I. (2014) Poroid fungi of Europe // Synopsis Fung. 31: 1-455.

Sowerby J. (1799) Coloured figures of English fungi or mushrooms. Vol. 2. London, tabs 121-240.

Tura D., Zmitrovich I. V., Wasser S. P., Spirin W. A., Nevo E. (2010) Biodiversity of Heterobasidiomycetes and non-gilled Hymenomycetes (former Aphyllophorales) of Israel. A. R. A. Gantner Verlag K.-G., Ruggell, 566 pp.

Westhuizen G. C. A. (1971) Cultural characters and carpophore construction of some poroid Hymenomycetes // Bothalia 10: 137-327.

Westphalen M. C., Tomšowský M., Kout J., Gugliotta A. M. (2015) Bjerkandera in the Neotropics: phylogenetic and morphological relations of Tyromyces atroalbus and description of a new species // Mycol. Progress 14: 100.

Zmitrovich I. $\boldsymbol{V}$. (1997) Corticioid fungi: modern systematics and the problems of phylogeny // Mikologiya i fitopatologiya [Mycology and phytopathology] 31, 3: 79-91 [In Russian]. (3митрович И. В. Кортициоидные грибы: современная систематика и проблемы филогении // Микология и фитопатология, 1997. Т. 31, вып. 3. С. 79-91).

Zmitrovich I. V., Malysheva V. F., Spirin W. A. (2006) A new morphological arrangement of the Polyporales. I. Phanerochaetineae // Mycena 6: 4-56.

Zmitrovich I. V., Malysheva V. F., Malysheva E. F. (2009) The hyphal types of polyporoid and pleurotoid fungi: a terminology revision // Ukrainian botanical journal 66, 1: 71-87 [In Russian]. (Змитрович И. В., Малышева B. Ф., Малышева $\boldsymbol{E}$. Ф. Типы гиф полипороидных и плевротоидных грибов: терминологическая ревизия // Укр. бот. журн., 2009. Т. 66, № 1. С. 71-87).

Zmitrovich I. V., Malysheva V. F. (2013) Towards a phylogeny of Trametes alliance (Basidiomycota, Polyporales) // Mycology and phytopathology Mikologiya i fitopatologiya 47(6): 358-380. 